\title{
HUBUNGAN PERILAKU DENGAN KONSEP DIRI PADA PASIEN CHRONIC KIDNEY DISEASES YANG MENJALANI HEMODIALISA DIRUANG HEMODIALISA RSUD DR. MOEWARDI
}

\author{
Prasetyo Agung Nugroho ${ }^{1}$ \\ ${ }^{1}$ Kementerian Kesehatan Politeknik Kesehatan Surakarta Jurusan Keperawatan \\ Diterima : 3 Mei 2018, Disetujui : 10 Mei 2018
}

\begin{abstract}
Background. Chronic Kidney Diseases (CKD) is a progressive deviation of kidney, the kidneys are unable to function to maintain metabolic balance, so as to resolve the issue carried out various therapies one of which is dialysis or Hemodialysis (HD). CKD patients undergoing hemodialysis will experience physical and psychosocial problems that affect the behavior and self-concept. This research is to know the Relationship Between Behavior And Self-concept in patients at Chronic Kidney Diseases That Undergoing Hemodialysis In Hemodialysis Unit of Hospital Dr. Moewardi. Methods. This type of research is correlational with the design of cross sectional and analysis the data used is the test Product Moment Pearson. Research Result. The results of this research is there is a relationship between the behavior and self-concept of patients undergoing hemodialysis in Hemodialysis Unit of Hospital Dr. Moewardi. This is evidenced by Pearson Product Moment analysis test which obtained significance value ( $p$ value) $0,000<0,05(\alpha=5 \%)$. Conclusion. Behaviors related to self-concept in patients with CKD undergoing Hemodialysis.
\end{abstract}

Keywords: Behavior, Self-concept, Chronic Kidney Diseases

\section{PENDAHULUAN}

Chronic Kidney Disease (Gagal

Ginjal Kronis) merupakan salah satu penyakit yang dapat mengancam kesehatan. Berdasarkan estimasi Badan Kesehatan Dunia (WHO), secara global lebih dari 500 juta orang mengalami penyakit gagal ginjal kronik. Sekitar 1,5 juta orang harus menjalani hidup bergantung pada cuci darah (hemodialisa). Di Indonesia pada tahun 2009 termasuk negara dengan tingkat penderita gagal ginjal sebanyak tiga ribu orang, namun yang terdeteksi menderita gagal ginjal kronis tahap terminal dari mereka yang menjalani cuci darah (hemodialisa) hanya sekitar 4 ribu -5 ribu saja ini dari jumlah penderita ginjal yang mencapai 4500 orang (Riskesdas, 2013).

Pasien yang menjalani Hemodialisa akan mengalami masalah fisik, seperti kelemahan, gatal-gatal pada kulit, rambut tipis, penurunanan berat badan (malnutrisi) dan juga mengalami masalah psikososial seperti berdiam diri, tidak ingin bertemu dengan orang lain, merasa kecewa, putus asa, malu dan tidak berguna disertai keragu-raguan dan percaya diri yang kurang (Suharyanto, 2009).

Klien yang menjalani Hemodialisa akan mengalami perubahan psikososial yang dapat mempengaruhi konsep dirinya dalam kehidupan sehari-hari. Gangguan konsep diri klien yang menjalani 
Hemodialisa meliputi lima (5) komponen konsep diri, yaitu: gambaran diri (bodyimage) seperti klien akan mengalami perubahan bentuk tubuh menjadi kurus, kulit gelap dan gatal-gatal, oedem atau bengkak, wajah sembab dan perut yang membuncit, ideal diri (self-ideal) seperti klien akan merasa putus asa dan tidak mempunyai harapan dalam kehidupannya karena proses Hemodialisa yang membatasi kemampuannya dalam melakukan keinginannya atau menyelesaikan pekerjaan yang sesuai dengan kemampuannya, identitas diri (self-identity) seperti klien akan mengalami ketergantungan pada orang lain dalam melakukan perawatan dirinya dalam kehidupan sehari-hari, peran diri (self-role) seperti klien tidak bisa menjalani perannya secara maksimal semenjak menjalani hemodialisa baik dalam keluarga maupun perannya dalam aktivitas sosial atau pekerjaan, dan harga diri (self-esteem) seperti klien akan mengalami perasaan yang negatif terhadap diri sendiri dan kurang percaya diri terhadap kondisi atau perubahan fisik yang terjadi akibat dari penyakit yang dialaminya maupun efek samping dari terapi Hemodialisa (Suliswati et al., 2005; Suharyanto, 2009).

Memahami konsep diri sangat penting bagi perawat dalam memberikan asuhan keperawatan secara holistik dan utuh bukan hanya menyembuhkan penyakit saja tetapi juga menghadapi individu yang mempunyai pandangan, nilai dan pendapat tertentu tentang dirinya. Perawatan klien dengan gangguan konsep diri diperlukan dalam merawat klien pada setiap tatanan pelayanan, baik di komunitas, rumah sakit umum atau rumah sakit jiwa (Riyadi \& Purwanto, 2009).
Data dari studi pendahuluan di RS Dr. Moewardi pada bulan Desember 2014 di ruang hemodialisa terdapat 250 pasien gagal ginjal kronik yang menjalani hemodialisa rutin. Jumlah tersebut terdapat 100 pasien yang menjalani terapi hemodialisa reguler dua kali dalam satu minggu. Dari 10 pasien dan keluarga yang diwawancari dan diobservasi oleh peneliti 7 keluarga mengatakan pasien mengalami perubahan perilaku seperti merasa kurang percaya diri dan cenderung diam dan 3 mengatakan bahwa pasien tidak mengalami perubahan perilaku, sedang dari hasil wawancara 7 pasien mengatakan malu dengan keadaan fisiknya, takut akan kehilangan peran, merasa tak berguna dan mudah putus asa dan 3 pasien mengatakan dirinya tidak merasa terganggu dengan keadaannya. Dalam penelitian ini bertujuan untuk mengetahui hubungan perilaku dengan konsep diri pada pasien Chronic Kidney Diseases yang menjalani hemodialisa di ruang Hemodialisa RSUD Dr. Moewardi.

\section{METODE PENELITIAN}

Sebelum diuji bivariat, data diuji kenormalan data dengan uji kolmogorov smirnov. Data bivariat dilakukan untuk melihat hubungan perilaku dengan konsep diri pasien Chronic Kidney Diseases yang menjalani hemodialisa, yang dianalisis secara analitik menggunakan uji statistik parametrik yaitu menggunakan uji korelasi pearson product moment, jika distribusinya normal.

Berdasarkan uji normalitas data dengan menggunakan uji One Sample Kolmogorov Smirnov Test dengan taraf signifikansi $(\alpha) \quad 0,05$ melalui program SPSS for windows versi 17.0. Berdasarkan perhitungan uji normalitas diperoleh konsep diri nilai sig 0,150. Hal 
ini berarti data berdistribusi normal (nilai sig > 0,05) dan pada perilaku pasien CKD diperoleh nilai sig 0,056. Hal ini berarti data berdistribusi normal (nilai sig $>$ 0,05) sehingga uji statistik yang digunakan menggunakan uji korelasi Product Moment Pearson.

\section{HASIL PENELITIAN}

1. Karakteristik Responden

a. Distribusi Frekuensi Umur Responden

Distribusi umur responden dapat dilihat pada Tabel berikut ini :

Tabel 1. Distribusi Frekuensi Umur Responden (N : 50)

\begin{tabular}{ccccc}
\hline Karakteristik & Mean & Median & SD & $\begin{array}{c}\text { Min- } \\
\text { Maks }\end{array}$ \\
\hline Umur & 33,26 & 27 & 14,909 & $16-65$ \\
\hline
\end{tabular}

Dari tabel diatas dapat diketahui bahwa dari 50 pasien gagal ginjal kronik di unit hemodialisa RSUD Dr. Moewardi rata-rata berumur 33,26 tahun dengan Standar deviation 14,909 dan umur terendah 16 dan tertinggi 65.

b. Distribusi Frekuensi Jenis Kelamin Responden

Distribusi frekuensi jenis kelamin responden dapat dilihat pada Tabel berikut ini :

Tabel 2. Distribusi Frekuensi Jenis Kelamin Responden

\begin{tabular}{lcc}
\hline Jenis Kelamin & Frequency & Percent \\
\hline laki-laki & 29 & 58.0 \\
Perempuan & 21 & 42.0 \\
\hline Total & 50 & 100.0 \\
\hline
\end{tabular}

Dari tabel diatas dapat diketahui bahwa responden terbanyak berjenis kelamin laki-laki sebesar 29 responden $(58 \%)$.

\section{Konsep Diri}

Distribusi frekuensi konsep diri responden dapat dilihat pada Tabel berikut ini :

Tabel 3. Distribusi Frekuensi Konsep Diri Responden

\begin{tabular}{lcc}
\hline Konsep Diri & Frekuensi & Persen \\
\hline Adaptif & 33 & 66.0 \\
Maladaptif & 17 & 34.0 \\
\hline Total & 50 & 100.0 \\
\hline
\end{tabular}

Berdasarkan tabel 3 menunjukkan bahwa konsep diri responden $(66 \%)$ pada konsep diri adaptif sebanyak 33 responden. Sedangkan prosentase konsep diri maladaptif (34\%) terdapat 17 responden.

3. Perilaku

Distribusi frekuensi perilaku responden dapat dilihat pada Tabel berikut ini :

Tabel 4. Distribusi Frekuensi Perilaku Responden

\begin{tabular}{lcc}
\hline Perilaku & Frekuensi & Persen \\
\hline Baik & 27 & 54.0 \\
Tidak Baik & 23 & 46.0 \\
\hline Total & 50 & 100.0 \\
\hline
\end{tabular}

Berdasarkan tabel 4 menunjukkan bahwa perilaku responden (54\%) pada perilaku baik sebanyak 27 responden. Sedangkan prosentase perilaku tidak baik $(46 \%)$ terdapat 23 responden.

4. Pengujian Hipotesis

Hasil pengolahan data dengan uji korelasi Product Moment dengan bantuan SPSS for windows versi 17.0 dapat diketahui $r_{\text {hitung }}$ adalah 0,677 dengan nilai p lebih kecil dari $0,05(0,000<0,05)$ yang artinya ada hubungan antara perilaku dengan konsep diri pasien CKD. 


\section{PEMBAHASAN}

1. Umur

Berdasarkan hasil penelitian karakteristik responden pada tabel 1 menunjukkan bahwa responden yang menjadi sampel penelitian rata-rata berumur 33,26 tahun dengan umur terendah 16 tertinggi 65 .

Menurut Riskesdas (2013) umur 26-35 merupakan umur yang rentan terhadap perubahan karena individu yang labil dan tak banyak dari mereka yang terjerumus kedalam hal-hal negatif seperti minum-minuman keras, merokok, menggunakan narkotika dan lain sebagainya, sedangkan umur 36-45 mulai ada proses kematangan usia. Berdasarkan hasil Riskesdas (2013) jumlah individu yang mengkonsumsi alkohol pada usia 26-35 tahun yakni sebesar 6,7\% meningkat dari 5,3\%, merokok 55,8\% meningkat dari $48,6 \%$, untuk penggunaan obat terlarang $1,2 \%$ meningkat dari $0,8 \%$. Selain itu umur sangat mempengaruhi terjadinya gagal ginjal kronik. Apabila umur penderita lebih dari 40 tahun, maka dinding arteri akan mengalami penebalan karena adanya penumpukan zat kimia yang semakin lama semakin bertambah, serta berkurangnya aktivitas yang dilakukan penderita dan makanan yang dikonsumsi pada umur 40 tahun menyebabkan penumpukan dan pembangkitan penyumbat peredaran darah ke jantung tidak lancar. Peredaran darah yang tidak lancar dapat mempengaruhi suplai darah ke ginjal sehingga menyebabkan kerusakan ginjal (Harianja, 2014). Hal ini sesuai dengan hasil penelitian yang dilakukan Yulinda (2002) di RSU Dr. Pirngadi Medan, yang menyatakan bahwa penderita gagal ginjal kronik meningkat secara nyata pada kelompok umur $>40$ tahun yaitu $(64,4 \%)$.

\section{Jenis Kelamin}

Hasil penelitian karakteristik responden berdasarkan jenis kelamin seperti tabel 4.2 menunjukkan bahwa sebagian besar responden berjenis kelamin laki-laki yaitu 58\% sedangkan responden perempuan sebesar $42 \%$. Hal ini sesuai dengan penelitian Septiwi (2011) yang menunjukkan bahwa pasien yang menjalani hemodialisa lebih banyak lakilaki yaitu (58\%) dibanding dengan perempuan $(41,6 \%)$. Secara teori empat faktor resiko utama dalam perkembangan penyakit ginjal kronis yaitu usia, ras, jenis kelamin dan riwayat keluarga (Price \& Wilson, 2005).

Jumlah pasien laki-laki lebih banyak dari perempuan kemungkinan dapat disebabkan oleh beberapa hal, salah satunya adalah pembesaran prostat pada laki-laki dapat menyebabkan terjadinya obstruksi dan infeksi yang dapat berkembang menjadi gagal ginjal. Selain itu, pembentukan batu renal lebih banyak diderita oleh laki-laki karena saluran kemih pada laki-laki lebih panjang sehingga pengendapan zat pembentuk batu lebih banyak dari pada wanita. Hal ini sejalan dengan penelitian Krisna (2010) yang menyebutkan bahwa laki-laki menempati prosentase $60,8 \%$ kejadian batu ginjal dibandingkan dengan perempuan. Terdapat sejumlah faktor yang mempengaruhi, pertama anatomi saluran kencing laki-laki yang mudah terkena penyakit. Kemudian komposisi urine laki-laki mengandung kalsium oksalat bisa membentuk batu. Sementara sitrat bisa mencegah batu. Prevalensi diperkirakan penyakit batu ginjal terjadi $13 \%$ pada laki-laki dewasa dan $7 \%$ wanita dewasa. Laki-laki memiliki resiko 
2 hingga 4 kali lebih besar dari perempuan (Pramana, 2013). Laki-laki juga lebih banyak mempunyai kebiasaan yang dapat mempengaruhi kesehatan seperti merokok, minum kopi, alkohol dan minuman suplemen yang dapat memicu terjadinya penyakit sistemik yang dapat menyebabkan penurunan fungsi ginjal (Smeltzer dan Bare, 2001).

\section{Konsep diri}

Hasil penelitian karakteristik responden berdasarkan konsep diri seperti tabel 4.3 menunjukkan bahwa sebagian besar responden memiliki konsep diri adaptif 66\%. Konsep diri adalah pandangan seseorang terhadap diri sendiri (Arini, 2006). Menurut Rakhmat (2010) konsep diri terdiri dari konsep diri positif dan konsep diri negatif. Dalam bentuk esktrimnya konsep diri negatif adalah bentuk pengetahuan yang tidak tepat terhadap diri sendiri, pengharapan yang tidak realistis dan harga diri yang rendah. Ciri konsep diri yang positif adalah dalam pengetahuan yang luas tentang diri sendiri, pengharapan yang realistis dan harga diri yang tinggi.

Konsep diri positif menurut Rakhmat (2010) ditandai dengan :

a. Yakin dalam kemampuannya dalam mengatasi masalah.

b. Merasa setara dengan orang lain.

c. Menerima pujian tanpa rasa malu.

d. Menyadari bahwa setiap orang mempunyai berbagai perasaan, keinginan dan perilaku yang tidak seluruhnya disetujui masyarakat.

e. Mampu memperbaiki dirinya karena ia sanggup mengungkapkan aspek-aspek kepribadian yang tidak disenangi dan berusaha mengubahnya.

Konsep diri terdiri dari aspek fisik, psikis, sosial dan moral. Aspek fisik yaitu bagaimana penilaian individu terhadap segala sesuatu yang terlihat secara fisik yang dimilikinya seperti tubuh, kesehatan, pakaian penampilan. Aspek psikis meliputi pikiran, perasaan dan sikap yang dimiliki individu terhadap dirinya sendiri. Aspek sosial yaitu bagaimana peranan sosial yang diperankan individu mencakup hubungan antara individu dengan keluarga dan individu dengan lingkungan. Aspek moral merupakan nilai dan prinsip yang memberi arti dan arah dalam kehidupan individu. Faktor-faktor yang mempengaruhi konsep diri yaitu usia kematangan, penampilan diri, nama dan julukan, hubungan keluarga, teman-teman sebaya, kreativitas dan cita-cita (Hurlock, 2008).

Hal ini juga didukung oleh penelitian yang dilakukan oleh Reni Zulfitri (2011), yang berdasarkan uji statistik Chi Square didapatkan p 0,02 (p $<0,05$ ) yang berarti terdapat hubungan antara konsep diri dengan gaya hidup sehat lansia yang mengalami penyakit kronis di Panti Sosial Tresna Werdha Khusnul Khotimah Pekanbaru. Dengan demikian konsep diri mempengaruhi pembentukan gaya hidup sehat lansia dengan penyakit kronis.

\section{Perilaku}

Hasil penelitian karakteristik responden berdasarkan perilaku seperti tabel 4.4 menunjukkan bahwa sebagian besar responden memiliki perilaku positif 54\%. Perilaku manusia adalah refleksi dari berbagai gejala kejiwaan seperti pengetahuan, persepsi, minat, keinginan dan sikap. Hal-hal yang mempengaruhi perilaku seseorang sebagian terletak dalam diri individu sendiri yang disebut juga faktor internal sebagian lagi terletak di 
luar dirinya atau disebut dengan faktor eksternal yaitu faktor lingkungan (Notoatmodjo, 2007).

Perilaku yang optimal akan memberikan dampak pada status kesehatan yang optimal juga. Perilaku yang optimal adalah seluruh pola kekuatan, kebiasaan pribadi atau masyarakat baik secara sadar ataupun tidak yang mengarah kepada upaya pribadi atau msyarakat untuk menolong dirinya sendiri dari masalah kesehatan. Menurut Notoatmojo (2007) perilaku kesehatan dipengaruhi oleh 3 faktor, yakni faktor predisposisi, faktor pemungkin dan faktor pendukung. Hal ini juga didukung oleh penelitian yang dilakukan oleh Dian Komasari (2000), berdasarkan analisis dengan regresi ganda didapatkan $\mathrm{F}=22,468(\mathrm{p}<0,05)$ dan $R=0,620\left(R^{2}=0,384\right)$ yang artinya sikap permisif orang tua dan lingkungan teman sebaya merupakan prediktor terhadap perilaku merokok. Dimana lingkungan teman sebaya masuk dalam faktor pendukung sesuai teori yang dikemukakan oleh Notoatmojo.

5. Hubungan Perilaku dengan Konsep Diri Pasien Chronic Kidney Diseases yang menjalani Hemodialisa

Hasil penelitian ini menunjukkan adanya hubungan positif ( $\mathrm{r}_{\text {hitung }}$ adalah 0,677 ) antara perilaku dengan konsep diri pasien CKD yang menjalani Hemodialisa yang artinya setiap peningkatan perilaku disertai dengan peningkatan konsep diri.

Hal ini sesuai dengan teori yang dikemukakan oleh Wiknjosastro (2005) bahwa perilaku yang yang ditampilkan individu akan mengalami penyesuaian dengan perubahan fisik yang terjadi pada dirinya. Menurut Stuart dan Sudeen yang dikutip oleh Salbiah (2009) perilaku yang baik akan memiliki keseimbangan dalam kehidupan termasuk dalam konsep diri.

Pemikiran bahwa keyakinan, perasaan, penilaian-penilaian mengenai diri mempengaruhi perilaku adalah sebuah prinsip penting. Manusia memiliki konsep diri dan memiliki mekanisme untuk berinteraksi dengan dirinya. Mekanisme ini digunakan untuk menuntun perilaku dan sikap. Misalnya seseorang memiliki pemikiran yang positif mengenai dirinya, maka setiap apa yang terjadi pada diri orang tersebut akan disikapi dengan baik pula. Proses ini disebut sebagai prediksi pemenuhan diri (Self-fulfilling Prophecy) atau pengaharapan akan diri yang menyebabkan seseorang untuk melakukan perilaku tertentu sehingga harapannya terwujud (West dan Turner, 2008).

Menurut Matthews, dkk (2008) pemikiran yang optimisme mempengaruhi bagaimana individu melihat dunia dan sikap mereka dalam menghadapinya, ini merupakan faktor yang mempengaruhi perilaku. Individu sering mengartikan bahwa penyakit kronis merupakan penyakit seumur hidup dan itu mempengaruhi pemikiran individu tentang kesehatan yang baik

Hal ini juga didukung dengan penelitian sebelumnya yang dilakukan oleh Irnawati (2009), berdasarkan hasil analisis dengan menggunakan teknik analisis korelasi Product Moment diperoleh nilai $\mathrm{r}$ sebesar 0,510 dan $\mathrm{p}<$ 0,01 yang berarti ada hubungan yang sangat signifikan antara perilaku melayani dengan konsep diri. Dengan demikian, semakin tinggi perilaku melayani maka semakin tinggi konsep diri dan sebaliknya.

\section{KESIMPULAN DAN SARAN}

Kesimpulan dari penelitian ini adalah Pasien Chronic Kidney Diseases di 
unit Hemodialisa RSUD Dr. Moewardi sebagian besar adalah laki-laki sebesar 29 responden $(58 \%)$, rata-rata berumur 33,26 tahun, sebagian besar memiliki konsep diri adaptif (66\%) sebanyak 33 responden, sedangkan konsep diri maladaptif (34\%) sebanyak 17 responden, sebagian besar memiliki perilaku baik sebesar 27 responden (54\%), sedangkan perilaku tidak baik (46\%) sebesar 23 responden dan ada hubungan yang signifikan antara perilaku dengan konsep diri dimana $\mathrm{p}=0,000(\mathrm{p}$ $<0,05)$. Jadi perilaku mempengaruhi konsep diri pasien Chronic Kidney Diseases yang menjalani Hemodialisa.

Saran bagi tenaga keperawatan pemberian informasi mengenai hemodialisa secara keseluruhan penting dilakukan agar klien mampu melakukan penyesuaian diri terhadap perubahan yang terjadi, walaupun perilaku klien CKD yang menjalani terapi hemodialisa adaptif namun masih ada klien yang memiliki perilaku maladaptif. Sehingga klien mampu beradaptasi dengan baik terhadap perubahan-perubahan yang terjadi dalam hidupnya.

Bagi peneliti selanjutnya diharapkan bisa mengembangkan penelitian ini, dengan menambah variabel penelitian mengenai faktor-faktor yang mempengaruhi konsep diri dan perilaku seperti motivasi keluarga, usia, pendidikan, pengetahuan, dukungan teman sebaya, budaya, pekerjaan keyakinan dan nilai.

\section{DAFTAR RUJUKAN}

Arini, A. (2006). Konsep Diri Positif, Menentukan Prestasi Anak. Yogyakarta :Kanisius
Harianja, A. A. (2014). Pengaruh Umur dengan Kejadian Gagal Ginjal Kronik

Hurlock, E. (2008). Psikologi Perkembangan Suatu Pendekatan Sepanjang Rentang Kehidupan. Jakarta : Erlangga

Komasari, D. (2000). Faktor-Faktor Yang Mempengaruhi Perilaku Merokok Di Wilayah Kerja Puskesmas Wonosari. Skripsi. UGM

Notoatmodjo. (2007). Metodologi Penelitian Kesehatan. Jogjakarta: Rineka Cipta

Notoatmodjo. (2007). Promosi Kesehatan dan Perilaku Manusia. Jakarta : Salemba Medika

Pramana, DT. (2013). Batu Ginjal. http://pramana-d-t-

fkm11.web.unair.ac.id/artikeldetail-71305-umum-

BATU\%20GINJAL.html. Diakses tanggal 12 Juni 2015

Price, S. A., Wilson, L. M. (2006). Pathofisiologi Konsep Klinis Proses- Proses Penyakit. Edisi 6. Jakarta: EGC

Rakhmat, J. (2010). Psikologi Komunikasi. Bandung : Rosdakarya

Riyadi \& Purwanto. (2009). Hubungan Antara Lama Hemodialisa Terhadap Tingkat Kebutuhan Spiritual Klien Hemodialisa di RSUDBanyumas. Diperoleh dari http://keperawatan.unsoed.ac.id/cont ent/hubungan-antara-lamahemodialisa-terhadap-tingkatkebutuhan-spiritual-klienhemodialisa-di? language $=$ ja.

Salbiah. (2008). Konsep Diri. www.duniapsikologi.dagdigdug.co $\mathrm{m}$ diunduh tanggal 12 Juni 2015

Smeltzer, S. C. dan Bare, B. G. (2006). Buku Ajar Keperawatan Medikal 
Bedah Brunner \& Suddarth. Jakarta : EGC

U. S Renal Data System. (2009). USRDS 2009 Annual Data Report : Atlas of end stage renal disease in the United State

West, R. dan Tuener, R. (2008). Pengentar Teori Komunikasi: Analisis dan Aplikasi edisi 3. Jakarta: Salemba Humanika

Wiknjosastro, H. (2005). Ilmu Kebidanan. Jakarta : YBPSP

Yulinda. (2002). Karakteristik Penderita GGK Yang Di Rawat Inap Di RSU Dr. Pirngadi Medan. Skripsi. Fakultas Kesehatan Masyarakat USU, Medan

Zulfitri, R. (2011). Hubungan Antara Konsep Diri Dengan Gaya Hidup Sehat Lansia Yang Mengalami Penyakit Kronis Di Panti Sosial Tresna Wreda Khusnul Khotimah Pekanbaru. Skripsi. Universitas Hasanuddin 